\title{
List of Reviewers to 31 December 2008
}

French Politics (2008) 6, 407. doi:10.1057/fp.2008.17

Helen Drake, University of Loughborough, UK

Jocelyn Evans, University of Salford, UK

Abel François, TELECOM ParisTech, France

John Huber, Columbia University, New York, USA

Piero Ignazi, University of Bologna, Italy

Jeffrey Karp, University of Exeter, $U K$

Michael Keating, European University Institute, Italy

Raymond Kuhn, Queen Mary, University of London, UK

John Loughlin, Cardiff University, $U K$

Sally Marthaler, University of Sussex, UK

Amy Mazur, Washington State University, USA

Anand Menon, University of Birmingham, $U K$

Craig Parsons, University of Oregon, USA

Ettore Recchi, University of Florence, Italy

Travis Ridout, Washington State University, USA

Nicholas Sauger, Institut d'Études Politiques de Paris, France

Jae-Jae Spoon, University of Iowa, USA

Nicholas Startin, University of the West of England, UK

Francesca Vassallo, University of Southern Maine, USA

Sarah Waters, University of Leeds, UK

Julien Weisbein, Institut d'Études Politiques de Toulouse, France 